\title{
A Synthesis of Current Issues in the Labour Regulatory Environment
}

Haroon Bhorat

Carlene van der Westhuizen

Development Policy Research Unit

Working Paper 09/135

February 2009

ISBN Number: 978-1-920055-71-4 


\section{Abstract}

During 2006 and 2007, a selection of research papers, in the main written by labour law experts, have provided critical input and guidance on the nature of the debate around the efficiency of the labour regulatory environment in South Africa. In November 2007, key stakeholders from government, labour and business attended a workshop on the Labour Regulatory Environment in South Africa at the Mount Grace Hotel, Magaliesberg, where the results of the aforementioned studies were presented and debated. This paper is an attempt at synthesising these debates for a non-legal audience, of what some commentators have referred to as the 'Mount Grace Consensus'

Labour law experts generally agree that the current challenges in the regulatory environment have arisen disproportionately from the improper realisation of the labour market reforms introduced in the mid-1990s. The paper provides for an overview then of the key concerns amongst employers and employees and the various parameters of the economy's labour legislative and institutional environment. These traverse the areas of, interalia, hiring and firing clauses, interpretation of procedural fairness, Codes of Good Practice and the importance of efficient and effective institutions of the labour market.

\section{Acknowledgement}

This Working Paper is one in a series eminating from The Critical Research Projects funded by the Department of Labour. The project was commissioned to the Development Policy Research Unit (headed by Prof Haroon Bhorat at the University of Cape Town) and the Sociology of Work Unit (led by Prof Eddie Webster at the University of the Witwatersrand) under the auspices of the Human Sciences Research Council (led by Andre Kraak).

Development Policy Research Unit Tel: +27216505705 Fax: +27216505711
Information about our Working Papers and other published titles are available on our website at: http://www.dpru.uct.ac.za/ 


\section{Contents}

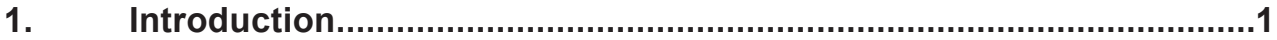

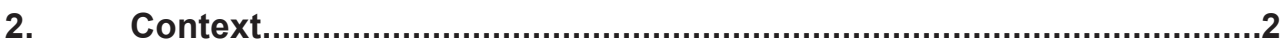

2.1 International Conventions, Constitution and Labour Regulation..................2

2.2 Changing Labour Market Environment................................................

3. Unfair Dismissals and Unfair Labour Practices...............................6

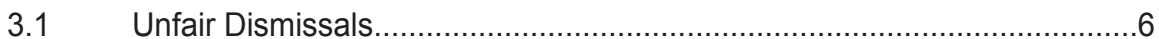

3.11 Dismissal for Misconduct and Incapacity...................................

3.1.2 Dismissal for Operational Requirements.....................................

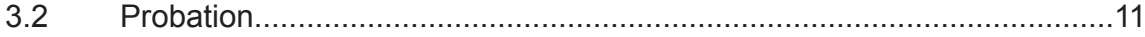

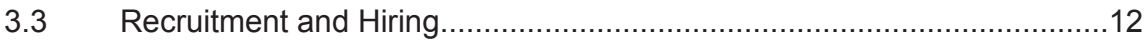

3.4 Residual Unfair Labour Practices.......................................................13

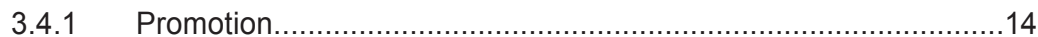

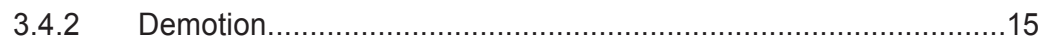

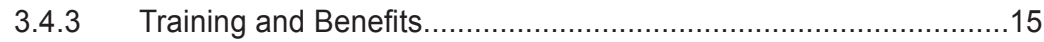

3.4.4 Discipline Short of Dismissal..................................................16

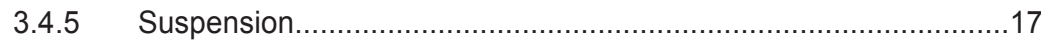

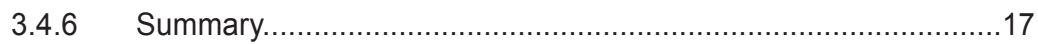

4. Labour Market Institutions..........................................................19

4.1 Bargaining Councils.........................................................................19

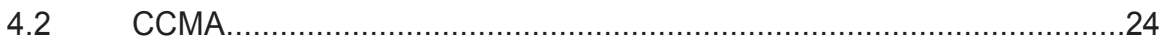

The Process of Dispute Resolution................................................................24

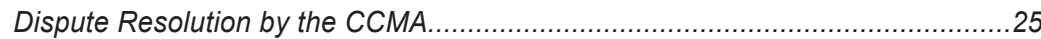

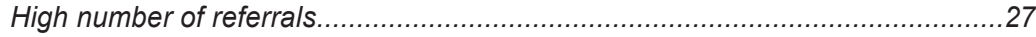

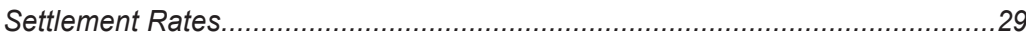

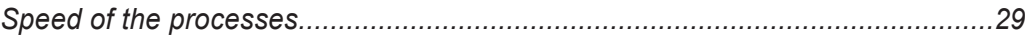

Over-emphasis on procedural fairness..................................................... 31

Impact of Labour Court decisions on the CCMA.................................... 32

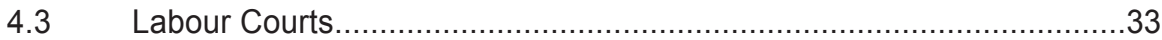

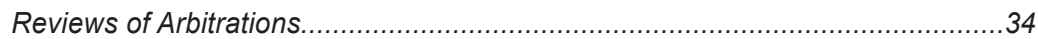

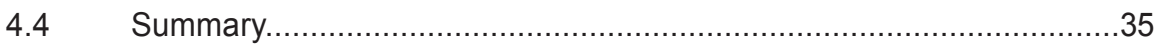

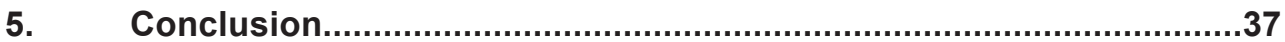

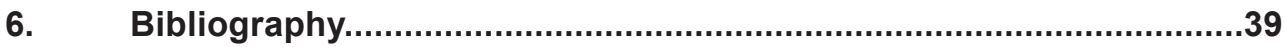




\section{Introduction}

Over the past two years, a selection of research papers, in the main written by labour law experts, have provided critical input and guidance on the nature of the debate around the efficiency of the labour regulatory environment in South Africa. In November 2007, key stakeholders from government, labour and business attended a workshop on the labour regulatory environment in South Africa, where the results of the aforementioned studies were presented and debated. ${ }^{1}$

This paper is a synopsis of the above-mentioned body of research and implicitly incorporates the tenor and content of the inputs at that workshop. The study is intended for a non-legal audience with the expressed aim of presenting the key issues in the current regulatory debate in a manner which is accessible to those outside the labour law profession.

Labour law experts generally agree that the current challenges in the regulatory environment have arisen disproportionately from the improper realisation of the labour market reforms introduced in the mid-1990s. Furthermore, the reforms understandably did not anticipate, and therefore provide for, the evolving nature of the labour market since 1994. Key relevant shifts here, has been a labour market characterised by increasingly atypical forms of employment.

The paper firstly reviews, in brief, the context, in terms of the wider legal framework and the labour market environment in the South African economy. Section 3 focuses on the key legal debates around unfair dismissals and unfair labour practices. In each of these areas, the main concerns are presented, along with the experts' suggestions on how to best address these challenges. Section 4 presents the challenges faced by the key labour market institutions, as well as possible areas for policy intervention. Section 5 concludes.

1 Labour Regulatory Environment in South Africa, 19 November 2007, Mount Grace Hotel, Magaliesberg. 


\section{Context}

When debating the key issues in the labour regulatory environment, it is important to consider the wider legal framework - such as the relevant international conventions, the South African Constitutions and the set of South African labour laws - as well as the labour market environment which provides the context for the implementation of labour market regulations. These parameters, in fact, remain at the core of any discussion around labour regulation in South Africa.

\subsection{International Conventions, Constitution and Labour Regulation}

South Africa is a member of the International Labour Organisation (ILO) and as such has ratified a number of ILO Conventions. This means that the country's labour legislation and regulations have to comply with the ILO Constitution and those ratified Conventions. Amongst others, these obligations include upholding the rights to freedom of association, to engage in collective bargaining, to equality at work and to eliminate forced labour and child labour (Cheadle, 2006: 4; Van Niekerk, 2007: 6).

The South African Constitution has a Bill of Rights that entrenches various rights that has to be taken into account when labour regulation is drawn up and implemented. These include the rights to equality, freedom of assembly, access to courts and administrative justice and also labour rights. Section 23 of the Constitution specifically relates to labour relations. It states that "everyone has the right to fair labour practice" and sets out the rights of workers, employers, trade union and employer organisations (RSA, 1996). These rights can be limited by a law of general application but only if it meets certain standards of justification set by the Constitution (Cheadle, 2006: 4).

The incoherent and inconsistent, and in many cases, still racist, system of industrial relations which characterised the pre-1994 era was clearly in need of significant overhaul with the advent of democratic rule. Within the labour market policy environment, the immediate period following the election of the first majority government was characterised by a frantic process of recasting the country's labour regulatory environment. The outcome of negotiations between employers and employees as well as significant rewriting of existing laws, were four key pieces of legislation. These 
are the Labour Relations Act (LRA) of 1995, the Basic Conditions of Employment Act (BCEA) of 1997, the Employment Equity Act (EEA) of 1998 and the Skills Development Act (SDA) of 1999. The LRA and BCEA were amended in 2002, while the Employment Equity Act was amended in 2006. These four Acts provide the legal foundation for the South African labour market.

The LRA, in addition, provided for a Code of Good Practice, to set guidelines for the processes to be followed by employers and the labour market institutions in implementing the labour legislation. At the time, it was envisaged that the Code would be updated on a regular basis in order to incorporate the judgements of the Labour Courts which would then provide further guidance on how the legislation should be interpreted. (Bhorat \& Cheadle, 2007: 11).

These legal parameters are important, as any discussion around labour legislation and potential reform has to take account of the above. Many economists' debates often ignore these facets and hence may end up, unfortunately, sounding superfluous.

\subsection{Changing Labour Market Environment}

While the section above has highlighted the importance of considering the broader legal context when discussing labour market regulation and reform, it is also important to consider that the labour market is not static, and that labour regulation and any regulatory reforms must account for the evolving labour market as well as changes in society and the economy in general. ${ }^{2}$

Within an environment of rising employment (and unemployment) levels, the South African economy has also witnessed a steep increase in atypical employment since the mid-1990s. Atypical employment includes arrangements such as outsourcing, labour brokering and part-time contracts (Bhorat et al, 2007: 50), as well as informal employment and self-employment. Workers engaged in atypical forms of employment generally enjoy very limited or no protection under the current labour legislation.

$2 \quad$ This section incorporates comments and discussions by participants at a workshop on the Labour Regulatory Environment in South Africa, 19 November 2007, Mount Grace Hotel, Magaliesberg. 
One of the key problems is that atypical employment can take such a variety of forms and each of these "types" presents its own set of challenges. It is therefore crucial to address the definition and measurement of atypical employment. Certain forms of atypical employment may be working quite well. Long-term fixed contracts are an example of atypical employment, but these workers are generally not particularly vulnerable or in need of protection. It has further been argued that atypical employment suits the needs of certain industries. In the service industry in particular, atypical employment is useful to deal with seasonality and any regulatory reform needs to take this into account.

It is not only the definition of atypical employment that is problematic. Differentiating between temporary and permanent employment can also be problematic. A classic example of this problem is the contract cleaning industry - employment is this industry is generally described as temporary based on the fact that a contract has been signed for a limited time period. It can, however, also be defined as formal employment, as a formal contract of employment has been drawn up and contractual law applies.

The issue of "triangular" employment is another example of where current labour legislation provides no guidelines on how to deal with the situation. In this employment relationship there are three parties, namely the employee, the employer (or client) and the labour broker or agency. In this scenario, the worker has no protection or rights - if the client/employer wants to fire a worker, the worker does not enjoy any protection against unfair dismissal. There is evidence that temporary employment services are used by employers who want to circumvent labour regulations. It has been suggested that these brokers or agencies should be required to register with the Department of Labour which may make it easier to monitor their activities.

Another feature of the post-apartheid labour market has been the increase in the number of Small, Micro and Medium enterprises (SMMEs). It has been suggested that SMMEs suffer excessively under the burden of labour legislation and that they generally do not have the financial or administrative resources to comply with all regulatory requirements. This does not, however, imply that SMMEs should be exempt from regulatory requirements. Complete exemption for SMMEs may act as a perverse incentive where larger employers deliberately reduce their workforce to circumvent 
labour regulation. ${ }^{3}$ In order to address the regulatory burden on SMMEs it is, however, critical that we establish the exact extent of the burden on SMMEs and how it maybe inhibits the growth of SMMEs.

In summary, when reviewing the key issues in the regulatory debate, it should always be kept in mind that any reforms have to be informed by the wider legal framework within which they operate and regulatory fixes should always be based on an accurate empirical appreciation of changing labour market conditions and dynamic in an economy.

3 Evidence from India suggests that the size of employer stipulations in its labour regulations acted as a deterrent to manufacturing firms realising economies of scale (Besley \& Burgess, 2004). Others have argued that the global competitiveness of Indian manufacturing was inadvertently undermined as a consequence. 


\section{Unfair Dismissals and Unfair Labour Practices}

Some of the most widely debated issues in the labour regulatory environment revolve around the provisions for and remedies against unfair dismissals and unfair labour practices in the LRA. ${ }^{4}$ Section 185 of the LRA states that "every employee has the right not to be (a) unfairly dismissed; and (b) subjected to unfair labour practice (LRA, 1995). The only employees that do not enjoy these rights are those that are excluded from the LRA itself (Van Niekerk, 2007: 15).

\subsection{Unfair Dismissals}

The LRA, in conjunction with the Code of Good Practice: Dismissal provides the course of action that has to be followed when an employer wishes to dismiss a worker. The LRA defines what is meant by "dismissal", what is an "automatically unfair dismissal" and also what can be considered a "fair" reason for dismissal, that is, reasons related to misconduct, incapacity and operational requirements. The act also requires that any dismissal must be done in accordance with "fair procedure" by following the guidelines set out in the Code of Good Practice. It also sets out the remedies available to employees who feel that they have been unfairly treated (RSA, 1995).

In terms of fairness, two aspects have to be considered. A dismissal has to be substantively fair. This means that, the reason for the dismissal must be fair and given the provisions of the LRA can only be related to misconduct, incapacity or operational requirements. A dismissal also has to be procedurally fair, in other words the procedure followed in the dismissal has to be fair. The standards of fairness are supposed to be set out in the Code of Good Practice, with it in essence providing the guidelines to be followed when dismissing for reasons for misconduct, incapacity and operational requirements. At the time of drafting the LRA, the intention was for the Code of Good Practice to be updated regularly to keep up to date with decisions made by the Labour Courts and the CCMA. In addition, the Code should also allow the opportunity to depart from the guidelines if the circumstances can justify it (Bhorat \& Cheadle,

$4 \quad$ While dismissals are not, of course, the only area of regulatory debate, the issues have certainly dominated recent discussion, hence our focus here. 
2007: 11, Cheadle, 2006: 26, 27). In the section below we first discuss dismissals for misconduct and incapacity before moving on to dismissals for operational requirements.

\subsubsection{Dismissal for Misconduct and Incapacity}

As mentioned above, dismissals have to be fair in terms of the procedures followed. The guidelines for the steps to be followed in the case of a dismissal for misconduct and incapacity are set out in the Code of Good Practice. These guidelines require the employer to first conduct an investigation to determine whether there are grounds for dismissal and then to notify the employee of the allegations in a language and in a format that the employee can understand. The employee should be allowed to respond and be given enough time to prepare a response. In addition, assistance from a trade union representative or fellow employee is allowed. After the enquiry the employer should notify the employee of the outcome, preferably in writing. The Code states quite specifically that the investigation "does not need to be a formal enquiry" (RSA, 1995: 151).

It has been argued, however, that the way in which employers have been interpreting the requirements for procedural fairness is overly strict and results in complex predismissal hearings in the workplace. These employers are often influenced by labour consultants, lawyers, arbitrators and judges who continue to follow the procedures developed under the old LRA. While these onerous requirements of procedural fairness place huge burdens on employers (particularly SMMEs), they do not play any role in promoting workers' rights (Cheadle, 2006: 29; Van Niekerk, 2007: 20). It appears that the main beneficiaries of this approach may indeed be the providers of advice and services to employers and employees. It has also been suggested that the overly strict interpretation of procedural fairness have contributed to employers increasing their use of atypical employment in order to avoid dealing with the perceived requirements (Van Niekerk, 2007: 24).

Experts agree that the responsibility for changing the (overly) strict and complex procedural requirements rests on the shoulders of the institutions responsible for dispute resolution such as the Labour Courts and the CCMA. They should lead by example by changing their approach and not demanding more technical pre-dismissal procedures than required by the Code of Good Practice (Cheadle, 2006: 29 \& Van Niekerk, 2007: 
23). (In Section 4 we return to this issue in our discussion of labour market institutions). As Roskam (2007: 13) points out, this may require extensive education and training of all stakeholders, including arbitrators, human resource personnel and trade union representatives, to ensure that they are aware of what is actually required by law in terms of procedural fairness. In addition, he also suggests that the Code should be changed to require that compensation for substantive unfairness should be greater than compensation for procedural unfairness in order to de-emphasise procedural fairness.

The financial burden on SMMEs is particularly large. At the moment the Code allows a different approach to be taken with regard to dismissals for incapacity and misconduct depending on the number of workers employed in the company (RSA, 1995: 150). It does not, however, present guidelines on how SMMEs should conduct dismissals and currently the Labour Court and the CCMA do not treat SMMEs any differently than other employers when a dismissal is challenged by the affected employees. Suggestions on how to deal with this situation range from the exemption of SMMEs from unfair dismissal laws completely (Van Niekerk, 2007: 18) to adapting the Code of Good Practice to set specific guidelines for dealing with small business (Roskam, 2007: 13) or even establishing a separate Code for SMMEs (Cheadle, 2006: 45).

Currently the laws on dismissal apply to all employees, regardless of their level of seniority or skill. It has been suggested that senior managers and even professionals can be excluded from protection from unfair dismissal as they are adequately protected in terms of their employment contracts. Some evidence also suggests that senior managers use the free services offered by the CCMA to get large financial settlements (Cheadle, 2006: 28; Van Niekerk, 2007: 15).

While South Africa has not ratified the ILO Convention No. 158 (Termination of Employment Convention 1982), it provides the international standard against which the current laws of dismissal can be evaluated. In terms of Convention No. 158, both small businesses and senior management can be excluded the laws on unfair dismissal (Van Niekerk, 2007).

A number of problems have been identified with the Code of Good Practice: Dismissal. The most critical is that the Code of Good Practice has not been updated to keep up with the new decisions and judgements by the CCMA and the Labour 
Court (Cheadle, 2006: 27). As a result the Code has become outdated and one of the key recommendations that labour lawyers agree on is that it should be updated as a matter of urgency. In addition, this should be a regular occurrence and the speed at which changes are negotiated at Nedlac should be addressed. (Cheadle, 2006: 26, 27; Roskam, 2007: 13).

\subsubsection{Dismissal for Operational Requirements}

Dismissal for operational requirements refers to retrenchment. In terms of Section 188 an employer may retrench workers if there is a fair reason based on its operational requirements. The test of substantive fairness (that is, if the reason for retrenchment is considered to be fair) has been interpreted in different ways by the Labour Court and the Labour Appeals Court, varying from retrenchment being recognised as a legitimate way to increase profits to it being allowed as a "measure of last resort". It is expected that this debate will continue in the courts (Roskam, 2007: 15, 16).

Again, when employees are retrenched certain guidelines and procedures have to be followed and these are set out in Sections 189 and Section 189A of the LRA (LRA, 1995). The guidelines set out in Section 189 refer to the procedures that should be followed to ensure that proper consultation takes place with all relevant parties in order to try and find a way to minimise the number of workers to be retrenched, change the timing of dismissal, mitigate the adverse effects of retrenchment or even avoid retrenchment completely. Consultation is also required to determine the appropriate method of retrenchment, the selection criteria and severance pay. Written notice has to be given by the employer to the workers with all relevant information and the workers should be given the opportunity to make presentations on any issue relevant to the proposed dismissals. The guidelines apply to all employers, irrespective of the number of workers it employs. In other words, SMMEs also have to follow the above procedures. In addition, the procedures have to be followed regardless of the number of proposed retrenchments, meaning that even if only one employee is to be retrenched the procedures set out in Section 189 have to be followed. As Van Niekerk highlights (2007: 26), this can be very impractical in, for example, the dismissal of a domestic worker.

In the 2002 amendment to the LRA, Section 189A was added, which to a certain extent recognises the difficulties SMMEs face by excluding them from Section 189A. 
Section 189A is only applicable to employers with more than 50 workers. In addition, it only applies when the number of retrenchments during a year is more than a certain threshold. This section prescribes the procedures and timeframes for negotiations. It also introduced the option of the facilitation of retrenchment negotiations and the right to strike over the fairness of the reason for the retrenchments (Roskam, 2007: 18; Van Niekerk, 2007: 26).

A number of problems have, however, been identified with Section 189A. Roskam (2007: 19) states that both union members and employees find the section difficult to understand. The different threshold requirements for different size employers are also difficult to justify. ${ }^{5}$ If workers choose to strike about the substantive fairness of the retrenchment under Section 189A and the matter appears before the Labour Court, different tests apply than in the case of SMMEs who fall under Section 189 only. Roskam (2007: 20) argues that all businesses should be treated equally with regard to the test of substantive fairness and that workers at small businesses should also be allowed to strike over the operational decision that resulted in the retrenchments.

International standards, as set by ILO Convention No. 158, allows for requirements of notification and consultation to be limited to when the proposed number of workers to be retrenched is above a certain threshold (Van Niekerk, 2007: 25). It has therefore been suggested that Section 189 be amended to limit the requirements of notification and consultation when less than a certain number of employees are to be retrenched in a certain time period (Van Niekerk, 2007: 27). In addition, it has also been suggested that SMMEs should be excluded from the more complex and cumbersome procedures required by the LRA when retrenching employees (Cheadle, 2006: 30).

Finally, the Code of Good Practice on Dismissals for Operational Requirements currently does not add anything to the guidelines in the LRA itself. The development of a new code has been proposed which would set out more clearly the procedures an employer should follow when he wants to retrench workers and a special section dealing with (a

$5 \quad$ These thresholds are ten employees if the employer employs up to 200 employees; 20 employees if the employer employs more than 200 but not more than 300 employees; 30 employees if more than 300 but not more than 400 workers are employed; 40 if more than 400 but not more than 500 workers are employed; and 50 employees if the employer employs more than 500. In addition, Section 189A applies only when the retrenchments are equal to or more than the number specified above. 
more simplified) process to be followed by SMMEs (and also households employing domestic workers) (Roskam, 2007: 21). Cheadle (2006: 30) has gone a step further and in line with his suggestion for SMME guidelines for the dismissal for misconduct and incapacity, proposes a completely separate code with simple procedural guidelines for SMMEs.

\subsection{Probation}

The level of protection that workers should enjoy during the probation period is currently a much debated issue. Many maintain that a probation period is critical to assess if an employee is suited to the particular workplace. It has, however, been argued that the difficulty of firing employees during the probation period is acting as a barrier to job creation. In other words, if it becomes easier to fire people during the probation period, employers may be encouraged to hire more workers. There is, however, no evidence to support this claim. All parties agree, however, that empirical research is required to establish if there is actually a link between reduced protection during probation and employment creation. The claim that a reduction in protection during the probation period will lead to employers hiring more workers should be empirically tested. Those opposed to reducing protection during probation, have argued that less protection during the probation period may be abused by unscrupulous employers, who may constantly dismiss workers during the probation period because it is relatively easy to do. Some labour law experts have, however, suggested that this particular issue is not really a major problem in the workplace, but rather being perceived as a major problem. More research may be required here as experiences may differ across sectors or by type of employment. It is also important to evaluate this issue against international evidence - it has been observed that most countries have moved towards removing some or all of the protections against dismissal during an initial "trial" period (Roskam, 2007: 24; Van Niekerk, 2007: 9).

The LRA includes "unfair conduct by the employer relating to ...probation" as one of the unfair labour practices, while guidelines for probation (including the provision of appropriate evaluation, training, instruction and guidance during this period) and dismissal during probation are set out in the Code of Good Practice: Dismissal (RSA, 1995). The Code only allows for dismissal during probation on the grounds of poor performance and not incompatibility or unsuitability in the workplace (Cheadle, 2006: 
19). The only "leniency" is that the Code states that the reason for dismissal during the probation period may be "less compelling" than in the case of dismissals after the completion of probation (LRS, 1995). In other words, it is slightly easier to dismiss a worker for poor performance during probation than after completion of this period. However, if an employee is dismissed for misconduct or incapacity during probation, the standards are not relaxed and all the requirements and procedures apply as if the employee has already completed the probationary period (Van Niekerk, 2007: 17).

As Cheadle (2006: 20) highlights, employers may side-step the issue of probation by entering into a fixed-term contract for a short period. If the employee is not suitable to or compatible with the workplace, the contract will simply not be renewed at the end of the period.

A solution that has been offered to address the issues around probation is the introduction of a "qualifying period" where all the protections against ordinary unfair dismissals (except of course for reasons that are automatically unfair such as discrimination and victimisation) do not apply (Cheadle, 2006: 20; Van Niekerk, 2007: 17,18). During this period, employers will be able to dismiss workers for poor performance or unsuitability without the normal protection. In order to prevent abuse, the qualifying period should take into account all previous periods of service with the employer or a related employer. This means that an employer will not be able to appoint

a worker for a qualifying period if that worker has already completed such a period with the same employer in a different position or with a different employer in a similar position. The length of qualifying periods can be changed via collective agreements, sectoral determinations and ministerial determinations. Van Niekerk (2007: 18) has suggested that qualifying periods can co-exist with probationary periods, with statutory qualifying periods and probation regulated by contract, and protection against abuse regulated by statutory and contractual remedies respectively.

\subsection{Recruitment and Hiring}

Current labour legislation does not regulate the recruitment and hiring practices of employers, with three notable exceptions which are informed by the constitutional obligations on the employer (Cheadle, 2006: 16, 17). The first exception relates to unfair discrimination under the Employment Equity Act with provision for judicial 
and administrative reviews. The second exception is the judicial review of employer decisions in relation to victimisation. The final exception is the judicial review under administrative law when hiring and recruitment takes place in the public service.

If an employer is found in breach of the Employment Equity Act, they will be subject to an administrative investigation and if found guilty will be subject to an administrative fine. The worker, who was subject to the discrimination, can sue the employer for damages, in the form of financial compensation. Cheadle, (2007: 17) has suggested that an amendment to the Employment Equity Act may be required to clarify that the victim can only sue for financial damages and not reinstatement. In terms of the right not to be victimised for one's trade union affiliation and beliefs, Cheadle as well Roskam (2006: 25) argue that the remedy of requiring an employer to re-hire a victimised employee should be available as without this remedy, employers may prefer to continue paying damages to workers and not allowing trade union organisation and activities in the workplace.

The final exception relates to recruitment and hiring in the public service. The State is required to comply with the basic values and principles governing public administration and at present challenges to these decisions are considered under administrative law. As a result, the normal remedy is to undo the unfair administrative action and not to pay damages. Cheadle argues that this remedy is unnecessary as public service employees now fall under the LRA.

\subsection{Residual Unfair Labour Practices}

The LRA and Code of Good Practice provide comprehensive guidelines for the procedures to be followed as well as the remedies (that is, the compensation options available to employees who have been found to be unfairly treated) for unfair dismissals - both for dismissals for misconduct, incapacity and for retrenchments. The LRA does not provide such comprehensive guidelines when it comes to what labour law experts define as "residual" unfair labour practices. Residual unfair labour practices refer to unfair treatment in relation to the following: promotion, demotion, training, benefits, discipline short of dismissal, suspension, and failure to reinstate or re-employ a former employee in terms of an agreement or contract (RSA, 1995; Cheadle, 2006: 14). 
Labour lawyers generally agree that the current definition in the LRA of what constitutes an unfair labour practice should be reconsidered. They argue that the LRA establishes the right to equality and the right to freedom of association. Any infringements of these rights can be dealt with under the LRA or individual contracts of employment. This means that when an employee is being treated unfairly with regard to promotion, demotion, training, benefits, discipline shore of dismissal, suspension and failure to reinstate or re-employ, there may be sufficient options available to the employee under the LRA or the individual employment contracts to address and remedy the unfair treatment. Hence, this suggests that some of the specific remedies for unfair labour practices in the LRA may be unnecessary (Cheadle, 2006; Van Niekerk, 2007). Experts, however, disagree about how to address these issues and while some suggest that the reference to unfair labour practices should be removed completely from the LRA, others prefer that they be replaced with clear statutory guidelines to be followed when unfair treatment is suspected. In the sections below we consider each of these unfair labour practices separately, highlighting the current challenges and possible solutions.

\subsubsection{Promotion}

It has been suggested that the decision to promote a worker is similar to the decision to hire a worker in the sense that they can both be considered "appointments" (see Cheadle, 2006: 21 \& Roskam, 2007: 26). There is, however, some disagreement over how the issue of promotion should be addressed. Some experts propose that promotions should be deleted as an unfair labour practice in the LRA (Cheadle, 2006: 21; Van Niekerk, 2007: 32), and that intervention should only be allowed under the same circumstances applicable to hiring practices, that is, in the event of unfair discrimination or victimisation. The opposing argument is that promotion is critically important because of the link to career development. If promotion is scrapped as an unfair labour practice, and the effected employee is not covered by a collective agreement, there will be no suitable process for dealing with a dispute about promotion. If there is no statutory guideline, it may also be more difficult for trade unions to negotiate on promotions in collective agreements (Roskam, 2006: 28).

Currently, the decision to promote an employee in the public service is considered to be an administrative action and administrative law (specifically the Promotion of Administrative Justice Act No 3 (PAJA)) applies when unfair treatment is suspected. It has been suggested that promotions in the public service should not be subject 
to review under PAJA, but rather be dealt with under the LRA as is the case with private sector promotions. In addition it has been suggested that in order to address corruption and poor service delivery in the public service, the Public Service Act should be amended to provide remedies specifically for corrupt and incompetent appointments in the public service (Cheadle, 2006: 22 \& Roskam, 2006: 27).

\subsubsection{Demotion}

A demotion can take place in three instances. Firstly, it can be a disciplinary measure; secondly, it can be an alternative to dismissal for incapacity; and thirdly, it can be used as an alternative to retrenchment (Cheadle, 2006: 22). The argument for removing demotion as an unfair labour practice is relatively simple. In all three instances identified above, an employee can only be demoted if he or she agrees to it. If the employee does not agree to the demotion, and the employer goes ahead with the demotion, it is a breach of the contract of employment. The employee can therefore sue for breach of contract or unfair constructive dismissal (Cheadle, 2006: 23; Roskam, 2007: 28). In terms of the BCEA, the Labour Courts have the jurisdiction to deal with the contractual disputes (Van Niekerk, 2007: 32).

Roskam (2007: 28,29), however, highlights a few flaws in the previous argument. If an employee is demoted, he may not perceive it as a dismissal and may not realise that he can challenge the demotion in the same way as he would have challenged an unfair constructive dismissal. If the demotion is deleted as an unfair labour practice, new guidelines should be provided on how employees can challenge a demotion. In addition, if a disciplinary code allows for demotion as a disciplinary measure it does not mean that an employee consented to demotion if he is found guilty of misconduct at a disciplinary hearing. Again, there should be guidelines for the employee in terms of how to challenge the fairness of such a demotion if demotion is scrapped as an unfair labour practice.

\subsubsection{Training and Benefits}

There appears to be general agreement that given the protection of fundamental rights in the LRA and the Employment Equity Act, as well as the provisions of the Skills Development Act, there is no need to include training in the definition of unfair labour practices (Cheadle, 2006: 21; Van Niekerk, 2007: 31). 
A benefit is a term of service and is the only term of service included in the definition of unfair labour practice. The fairness of terms and conditions of employment is not normally judged by the courts and fair standards are generally set through contracts, collective bargaining and legislation, with collective bargaining being the primary mechanism (Cheadle, 2006: 31).

The Labour Court has limited the interpretation of unfair labour practice in relation to benefits to only refer to the unfair treatment of an employee who has the right to a benefit in terms of an existing contract or collective agreement. The dispute cannot be about introducing the right to a benefit. This means that if an employee's contract does not provide for a benefit, but he feels that he is entitled to one, he is not allowed to claim that he is being unfairly treated. Legal experts have argued that unfair treatment in terms of benefits should be excluded from the definition of unfair labour practice. The reason for this is that if the provision of a benefit is included in the employment contract or negotiated as part of a collective agreement, the contract or collective agreement will provide the employee with the process to be followed and possible solutions if unfair treatment is experienced (Cheadle, 2006: 31, 32; Van Niekerk, 2007: 33).

In terms of creating a right to a benefit (that is, the introduction of a new benefit), this should be done via collective bargaining. Roskam (2007: 30), however, argues that this is not always the best remedy for resolving disputes about the introduction of new benefits. An example is the case where an employer has the discretion to grant a benefit but chooses not to and the reason for not granting the benefit appears to be completely irrational and cannot be connected to discrimination in terms of race and or gender. Bargaining or strike action may not be appropriate in such a case and workers should have the option of taking their grievances to the CCMA. The solution may be to provide guidelines in the LRA or Code of Good Practice on the boundaries of unfair conduct relating to the provision of benefits.

\subsubsection{Discipline Short of Dismissal}

Discipline short of dismissal refers to the power of the employer to discipline in a manner other than a dismissal. Warnings are the most common form of discipline and the argument for scrapping discipline short of dismissal as an unfair labour practice is based on the fact that these actions are mostly warnings. If a warning forms part of 
a sequence of events that eventually results in a dismissal, the fairness of the earlier warning and the subsequent dismissal will be evaluated under the test of fairness set out in the guidelines for dismissals (Cheadle, 2006: 24; Van Niekerk, 2007: 33).

Scrapping discipline short of dismissal as an unfair labour practice can, however it is argued, create certain problems. The affected employee may not have an opportunity to state his/her case, in other words the procedure will not be fair. Further problems relate to the subsequent impact of a warning. If an employee loses a promotion or does not get a bonus or salary increase because of a disciplinary record, the employee does not have the opportunity to challenge the earlier warning and its subsequent impact (Roskam, 2007: 31, 32).

\subsubsection{Suspension}

There is general consensus that widespread abuse of suspension occurs and this is a particularly common occurrence in the public sector, where suspensions have been known to last for extended periods of time (Cheadle, 2006: 24; Roskam, 2007: 32; Van Niekerk, 2007: 34). There is also agreement that suspension as a form of discipline is not problematic. This can only happen with the employee's consent and if the employee refuses and is subsequently dismissed the remedies for unfair dismissal will apply.

Suspension pending disciplinary action is the problematic issue and has to be reviewed. The rationale is to suspend an employee in order to prevent him/her to interfere in the investigation prior to a hearing in the case of misconduct or prevent him/her to repeat the misconduct. This is extremely unfair to the employee and can damage their reputation and career development. The proposed solution is the creation of a statutory obligation to limit the time-period of investigations and to make disciplinary hearings more efficient. In the public sector in particular, steps have to be taken to speed up the process and disciplinary hearings should ideally be conducted by an independent institution. There is general agreement that this is the one aspect of unfair labour practice that has to be addressed urgently and that reform of the regulation is required here to particularly address the abuse of suspension in the public sector. 


\subsubsection{Summary}

There is general consensus that the interpretation of procedural fairness (that is, the procedure to be followed) when dismissing workers for misconduct or incapacity is problematic, with employers generally following pre-dismissal processes that are much more complex than actually required by the law. In addition, it has been suggested that managers and skilled workers should be excluded from the laws on unfair dismissal. An earnings threshold, similar to the one used in the BCEA, ${ }^{6}$ may be an appropriate way to identify who should fall outside the ambit of the dismissal laws. When it comes to retrenchments, it has been suggested that the requirements with regard to notification can be limited when less than a particular number of workers is retrenched.

One of the key issues that all law experts agree on is that the Code of Good Practice for dismissal for misconduct, incapacity as well as retrenchments, should urgently be updated. Experts differ on how SMMEs should be treated, with some suggesting that they should be excluded from all legal requirements in relation to dismissals, while others feel that a separate Code of Good Practice should be drawn up for SMMEs.

While probation appears to be a critical issue, it has been found that this is not the case in practice and it has been suggested that the introduction of a "qualifying period" may be a way to deal with the current challenges around probation.

There is general agreement that the definition of what constitutes an unfair labour practice should be reviewed. Labour law experts do not, however, agree on how this should be done. Some suggest that all the unfair labour practices should be removed from the LRA, except suspension, while others prefer adding guidelines to the LRA or drawing up a separate Code of Good Practice to deal with unfair labour practices. Suspension pending disciplinary action is, however, very problematic, and requires immediate review, particularly given the abuse of suspension in the public sector.

$6 \quad$ According to the Basic Conditions of Employment Act, no 75 of 1997, the Regulation of Working Time does not apply to employees earning more than R149 736, before deductions, per annum (RSA, 2008). 


\section{Labour Market Institutions}

The extent to which the institutional environment often reinforces or hinders legislative provisions, is often under-appreciated in debates around labour market regulation. In most economies, institutions govern and manage the labour market. These include employer and employee organisations; the courts of law including specialist courts; institutions of dispute resolution; ministries of labour or employment; collective bargaining institutions; tripartite institutions and so on. These institutions will be differentially resourced in human and physical terms; will yield contrasting performances according to pre-set objectives; will have different governance structures, parameters of influence and ultimately power within the society and so on. Simply put, these range of factors, all of which are time and context-dependent, can and will fundamentally alter the manner in which labour regulatory provisions impact on the economy

\subsection{Bargaining Councils}

Bargaining councils (known as industrial councils before 1995) are the primary institutions involved in the statutory system of collective bargaining and wage determination in the South African labour market. Both trade unions and bargaining councils have been claimed to be contributing to inefficiencies in the labour market. The extensions of wage agreements to non-bargaining council members and non-union members are deemed to be particularly problematic and it has been argued that these extensions place unnecessary burdens on small and new businesses and contributes to the high unemployment rate in the country (Bhorat, van der Westhuizen \& Goga, 2007: 1).

The LRA provides the legislative framework for the establishment of bargaining councils. In terms of the legislation, one or more registered trade unions and one or more registered employers' organisations may establish a bargaining council for a sector and/or geographical area. Worker interests are therefore represented at a bargaining council by the party trade unions. The Act also provides for the State to be a party to any bargaining council if it is an employer in the sector and area in which the bargaining council is established (RSA, 1995: 22). In addition, the LRA prescribes the functions and powers of bargaining councils which amongst others, include the concluding and 
enforcing of collective agreements and certain dispute resolution functions (RSA, 1995: $22,23)$.

As noted above, the LRA sets out the procedures that have to be followed in order to have a collective agreement extended to non-bargaining council members. This includes that the Minister of Labour has to be satisfied that the trade unions whose members constitute the majority of the members of the party trade unions, and the party employer organisations that employ the majority of workers, voted in favour of the extension. A collective agreement is extended by publishing it in the Government Gazette.

One of the main criticisms levelled against the extension of bargaining council agreements is that large firms dominate the employer party bargaining during negotiations. These agreements (via the extensions) are then imposed on parties that were not involved in the negotiations. In practice, this has the effect of disproportionately excluding SMMEs. The extension to non-parties was the subject of fierce debate in the mid-1990s in terms of the unintended consequence it ostensibly had in increasing regulatory oversight and labour costs for SMMEs. The aim of the requirements in the LRA is to ensure that representivity thresholds are met before an agreement can be extended and that SMMEs are adequately represented on councils (Godfrey et al, 2006: 1). While it is generally difficult to accurately estimate the share of workers covered by extensions of bargaining council agreements, Godfrey et al. (2006: 24) have found that of the estimated 32,6 percent of formally employed workers (with the total excluding all Managers and Professionals in the private sector) covered by bargaining councils, only 4,6 percent were covered by extensions to agreements in 2004. In other words, extended bargaining council agreements covered a very small share of the labour force. This suggests that the extension to non-parties as a source of inefficiency in the labour market may be overstated. Put differently, the evidence that non-parties to the main bargaining council agreement suffer as a consequence of the automatic extension clause is not particularly strong.

The LRA also requires the constitution of a bargaining council to describe the procedures to be followed for a company to obtain exemption from some or all the clauses of an agreement. In order to comply with this, most of the councils have developed criteria for evaluating requests for exemptions as well as established 
independent bodies to hear appeals when an exemption has been denied. The criteria are usually published in their collective agreements. The agreements can include up to eight or nine criteria without any indication, though, of the weight of the criteria when an application for exemption is considered (Godfrey et al, 2006). This exemption system is the most important way in which the legislation accommodates SMMEs who may not be able to comply with the requirements of bargaining council agreements. Both employer parties and employers who are not parties (and therefore covered by the extension of an agreement) can apply for exemptions (Godfrey et al, 2006: 65).

Godfrey et al (2006: 71-79) examined data on exemptions from 17 bargaining councils for 2000, 2002 and 2004. They found that for those years, between 72 percent and 78 percent of applications for exemptions were granted - either in full, partially or conditionally. The majority of applications were granted in full. They compared these results with data obtained from the DoL for 2003 and 2004. The DoL data covers 44 councils in 2003 and 37 councils in 2004 and shows that in almost 80 percent of applications, exemptions are granted. This reinforces the view that the notion that the extensions-exemptions clauses within the regulatory environment cannot legitimately be viewed as problematic in the domestic labour market.

Bhorat, Van der Westhuizen and Goga (2007) investigated the role of bargaining councils in wage formation in the South African labour market in 1995 and 2005. The first step was to estimate the number of workers that were covered by bargaining council agreements in those two years. Figures show that only about 15 percent of formally employed workers were members of bargaining councils in 1995. While this figure doubled to an estimated 32 percent in 2005, this still meant that less than a third of the formally employed were covered by bargaining councils. (The figure for 2005 compares well with Godfrey et al's estimated bargaining council coverage of 32,6 percent for 2004.) In 2005, there were 48 bargaining councils, including the public sector councils. ${ }^{7}$ The councils vary from large, well organised national councils to very small, sub-sector specific regional councils.

$7 \quad$ In 1995 there were 62 private sector industrial councils. The decline in the number of councils predominantly reflects the amalgamation of regional councils into one national council, for example in the clothing and textile sectors. It should also be noted that a number of bargaining councils in 2005 were estimated using a number of sources, as there is no definitive list of bargaining councils available. 
Closer inspection of the increase in bargaining council membership between 1995 and 2005 revealed that is was almost entirely driven by the rapid rise in the bargaining council system for the public sector. The establishment of the Private Sector Coordinating Bargaining Council (PSCBC) meant that all non-managers (and even some levels of management) in the public sector were covered by wage agreements concluded in the PSCBC. In the private sector, however, bargaining councils have at best stagnated and at worse declined between 1995 and 2005. Despite aggregate employment growth in sectors such as Construction and Trade, bargaining council membership has not expanded accordingly. The only notable growth in bargaining council coverage was in the State Owned Enterprise-related sectors. Overall, the number of private sector workers covered by bargaining council agreements remained relatively stable at around one million. Simply put, bargaining council membership in the first decade of democracy has been characterised by an erosion of private sector bargaining council membership on the one hand and the rapid rise of this system of bargaining in the public sector.

At first glance, there did not appear to have been any significant remunerative advantage associated with bargaining council membership in either 1995 or 2005 when mean earnings were compared according to race and gender. Closer inspection of the mean earnings of bargaining council members in 2005, however, revealed significant wage advantages associated with membership of the PSCBC. At the aggregate level, public sector bargaining council members not only earned more than the private sector bargaining council counterparts, but also on average more than workers outside the bargaining council system. This trend was observed for males and females, African and Coloured workers, as well as when controlling for occupations.

A multivariate analysis was performed to attempt to isolate the specific impact of the membership of a bargaining council, union or both on earnings. The results from this analysis confirmed the tentative conclusions from the initial comparison of the level of mean wages. Hence, in 1995, workers in the bargaining council-non-union cohort only enjoyed a small wage premium relative to workers who were not covered by any institutional wage agreement. Workers in the union-bargaining council cohort did not enjoy any significant benefit in terms of average earnings. The establishment of the PSCBC, however, led to significantly higher wages being associated with public sector bargaining council membership in 2005 . The decline of the private sector bargaining 
council system, in turn, resulted in the membership of these councils not offering any wage benefit relative to their members who were not unionised - a contrast from a decade earlier. Workers who belonged to both a union and bargaining council in 2005 did, however, enjoy relatively higher wages. Union membership was associated with relatively higher earnings both in 1995 and 2005.

Overall, the evidence presented above suggests extensions of bargaining council agreements to non-parties to the main agreement account for a very small share of the formal labour force in South Africa. In addition, the exemption system appears to be working well, providing SMMEs with the opportunity to be exempted from some or all of the clauses of agreements. It was further shown that the increase in bargaining council membership since 1995 has been driven by the establishment of the PSCBC, while private sectors councils appear to be in decline. Finally, in 2005, only public sector bargaining council membership was associated with relatively higher wages, while workers belonging to private sector councils did not enjoy any wage benefits. There is therefore no evidence that bargaining councils (particularly in the private sector) contribute to inefficiencies in the labour market. The fact that the bargaining council system appears to be in decline, does, however, suggest that the current system of collective bargaining should be investigated with an eye on possible policy interventions to improve the system of collective bargaining.

The LRA provides for the right and not the duty to bargaining. This means that the LRA provides for a voluntary collective bargaining system, but includes incentives (particularly the ability of a bargaining council to extend its agreements) to encourage both unions and employers to participate in collective bargaining. In addition, the aim of the provisions in the LRA was to strengthen and expand the coverage of sector level collective bargaining (Cheadle, 2006: 33; Godrey et.al, 2007). The idea was that bargaining councils would set the framework for wages and working conditions at the sectoral level, while additional bargaining can take place at the workplace or enterprise level (Cheadle, 2006: 40).

The anticipated expansion of the collective bargaining system did not, however, materialise. The bargaining council system has remained strong in sectors where there is a tradition of collective bargaining and trade union organisation. Overall, however, bargaining council coverage remains fragmented (as evidenced by the proportionally 
small share of workers covered by agreements) and most councils are not truly sectoral (Cheadle, 2006: 37).

Labour law experts agree that imposing a duty to bargaining is not the preferred solution, but instead have highlighted the need for the Department of Labour to play a more pro-active role in promoting collective bargaining at the sectoral level. Specific suggestions include that the Department should revisit the mechanism for extending collective agreements, with one option being that less emphasis should be put on representivity and that an agreement should rather be judged on how well it is aligned with government's labour market policy. Others have proposed the development of specific programmes to support and assist bargaining councils, in order to disseminate best practices and to co-ordinate systems and resources (Cheadle, 2006: 41, Godfrey et al, 2007: 104). The formation of bargaining councils in sectors which have not traditionally engaged in collective bargaining should also be encouraged.

Finally, it has been suggested that sector level collective bargaining is the only way in which atypical employees (that is, those in casual or informal employment as well as the self-employed) can be afforded some protection in the labour market (Cheadle 2006: 42, Godfrey et al, 2007: 105). This means that sector level bargaining should take into account the specific needs of these workers and it also means that specific measures will have to be developed to involve unorganised workers in the bargaining process. Some international examples exist of where trade unions and organisations active in the informal economy have developed models for collective bargaining in the informal economy (See Godfrey et al, 2007: 105).

\subsection{CCMA}

The 1995 LRA created the Commission for Mediation, Conciliation and Arbitration (CCMA) as one of the main institutions to deal with labour disputes. In addition, the LRA prescribes the process that should be followed by the CCMA in resolving labour disputes. The CCMA was given the authority to provide accreditation to bargaining councils and privates agencies to perform dispute resolution functions (RSA, 1995). 


\section{The Process of Dispute Resolution}

Prior to discussing the operations of the CCMA, we briefly review the structure of the dispute resolution process in South Africa generally and the role of the CCMA specifically. Labour disputes can be classified into disputes of rights and disputes of interests, with disputes of interest being about new rights. ${ }^{8}$ The type of dispute determines the dispute resolute technique to be followed. The LRA provides for the determination of disputes of rights through adjudication by the Labour Courts or arbitration either by the CCMA, private dispute resolution institutions or Bargaining Councils. In the case of a dispute about rights, the first stage of dispute resolution is conciliation, which involves a neutral or acceptable third party assisting the two sides in coming to a mutually acceptable and binding solution. If conciliation is not successful, the case proceeds to arbitration. Issues that are more complex or that can affect public policy generally go straight to adjudication in the Labour Courts, while other issues go to arbitration. During arbitration, the dispute is settled by a neutral third party, with the arbitrator's decision final and binding. The LRA allows for the Labour Courts to review the outcomes of arbitrations under certain conditions. Disputes of interest are also first conciliated. If conciliation is not successful, the next phase may be industrial action (a strike or a lock-out), but this is not a common occurrence (Bhorat et al, 2007: 3, 4).

In 2002, the amendments to the LRA included two specific reforms that were aimed at speeding up the resolution of dismissal disputes. These are the "pre-dismissal" arbitration which, if both parties agree to the process, eliminates the need for both an internal hearing and arbitration. The second reform is the introduction of the "conarb" process, which allows for arbitration to start immediately after an unsuccessful conciliation process, merging the two processes into one (Benjamin \& Theron, 2007: 37).

\section{Dispute Resolution by the CCMA}

As noted, the process of dispute resolution by the CCMA is regulated by the LRA, both in terms of the action of the commissioners and the prescription of time-periods within

$8 \quad$ Disputes of interest can include claims for wage increases or beneficial changes to terms and conditions of employment. Disputes of right deal with a claim of one of the parties that their rights - as set out in a contract, statute or the Constitution - have been violated. In the labour market environment disputes of rights relate mostly to claims of unfair dismissal or unfair labour practice. (Levy \& Venter, 2006: 13). 
which certain actions have to take place. The LRA also requires the CCMA to conciliate and arbitrate disputes as quickly as possible.

The first step in the dispute resolution process is the referral of the dispute to the CCMA by the employee who thinks he has been treated unfairly. This has to happen within 30 days of the dismissal or within 90 days of the alleged unfair labour practice (RSA, 1995). ${ }^{9}$ The first step is the "screening" of the case to determine if it falls within the jurisdiction of the CCMA (Levy \& Venter, 2006: 24). If the correct referral process has been followed and the case falls under the CCMA's jurisdiction, the CCMA will appoint a commissioner and the case will proceed to conciliation. No legal representation is allowed at conciliation and the CCMA commissioner determines the process to be followed during this stage. The LRA requires the commissioner to resolve the dispute within 30 days of referral and at the end of the period, the commissioner has to issue a certificate stating if the dispute has been resolved or not (Bhorat et al, 2007: 4).

If the dispute was not resolved the next step is arbitration. The CCMA appoints a commissioner (arbitrator) whose decision is final and binding. If the arbitrator finds in favour of the employee, the LRA suggests reinstatement as the preferred remedy, but an employer may be ordered to pay compensation (Levy \& Venter, 2006: 16). No appeals against these decisions are allowed, but parties may approach the Labour Court to review an arbitration award.

The LRA requires the commissioner to select the most appropriate manner for the arbitration process in order to deal with the dispute fairly and quickly. The Act also requires the commissioner to use the minimum of legal formalities in dealing with the substantial merits of the case. Parties are allowed to give evidence, call witnesses, question the witnesses of the other party and address concluding arguments to the commissioner depending on the commissioner's choice of format for the proceedings. The LRA allows for either party to be represented by a legal practitioner, company director or a representative of a trade union or employer organisation. Again this has to be agreed upon by both parties and authorised by the commissioner. It has been argued that the CCMA has not created proper rules relating to the right to representation

9 A condonation application can be submitted in terms of the CCMA rules, which means that the CCMA considers a referral that was made outside the specified time periods (Levy \& Venter, 2006: 24). 
as intended by the 2002 amendments and that representation is unrestricted as a result (Bhorat et al, 2007: 5).

As mentioned before, the 2002 amendments created the "con-arb" process as an alternative option to dispute resolution. This basically means that conciliation and arbitration can take place as one process with two steps - arbitration will follow immediately if conciliation was unsuccessful. ${ }^{10}$ The purpose was to avoid the delay between the two separate processes and therefore reduce the cost (both financially and in terms of time) of the whole dispute resolution process. Again representation is only allowed at the arbitration phase (Bhorat et al, 2007: 5).

Before the introduction of the con-arb process, conciliation accounted for about half of the determinative processes. ${ }^{11}$ After the introduction of the "con-arb" process, the share of "pure" conciliation cases declined, but if the "con-arb" cases that are resolved at the conciliation stage are added to theses, the share of conciliation cases remained relatively stable between 2001/02 and 2005/06. The introduction of the "con-arb" process has had a similar impact on the total number of arbitration cases. Before the introduction of the "con-arb" process, the disputes concluded at the arbitration phase accounted for about 35 percent of cases. With the introduction of "con-arb", this share declined, but when cases concluded at the arbitration phase of "con-arb" are included, the share of arbitration cases remained relatively constant, with only a slight increase to about 40 percent in 2005/06. The remainder of cases can be broken down to preconciliation (6,5 percent in 2005/06), in limine ${ }^{12}$ (8.2 percent in 2005/06), other and withdrawn (3.03 percent in 2005/06). (All calculations were done by Bhorat et al, (2007) using data from the Case Management System database)

It has been estimated that about 70 percent of the employed in South Africa fall under the jurisdiction of the CCMA, with the rest subject to dispute resolution by bargaining councils (Levy \& Venter, 2006: 17). It has been suggested that a disproportionate share of semi-skilled workers fall under the bargaining council system, and as a result

\footnotetext{
$10 \quad$ Parties may object to the same commissioner presiding over both stages of the con-arb process.

11 The "determinative process" of a dispute is defined as the process at which a case is closed or resolved (Bhorat, et.al. 2007: 18).

12 In limine is a legal terms that refers to a technical argument to dismiss a case before its merits are considered.
} 
the CCMA has to provide services to a relatively higher share of skilled formal sector employees. This is certainly true of the private sector, where private sector bargaining councils do not cover Managers and Professionals, while the PSCBC does cover Professionals and certain levels of Management. In addition, the CCMA is the only dispute resolution institution that covers (unskilled) domestic workers and agricultural workers, as well as the majority of elementary workers. As a result CCMA coverage is relatively higher at the two extremes of the skills spectrum.

Four main types of disputes are referred to the CCMA, namely disputes over unfair dismissals (which include the whole range of dismissals relating to misconduct, incapacity, pregnancy, redundancy, and constructive dismissals), unfair labour practices, disputes arising over mutual interests and disputes over severance pay. Bhorat et al (2007: 11) have shown that between 2001/02 and 2005/06, disputes about unfair dismissals accounted for about seventy percent of all referrals to the CCMA.

The efficiency of the CCMA has been the subject of much debate and a number of specific challenges have been identified. These include the following:

- High number of referrals

- Settlement rates

- Time taken to resolve disputes

- Too much emphasis on procedural fairness

- Relationship between the Labour Court and the CCMA

\section{High number of referrals}

At the inception of the CCMA, it was estimated that it would have to deal with around 30000 cases a year. There is general agreement that this was a gross underestimation (Bhorat et al, 2007: 11; Van Niekerk, 2007: 39). During its first year of operation (1996/97), the CCMA only processed 2917 cases. This increased to almost 70000 in 1997/98 and to just under 130000 in 2005/06 (Bhorat et al, 2007, using the CCMA's Case Management System Database (CMS) and Annual Reports). Given that the case load is so much larger than anticipated, it has caused major financial and administration 
strain on the CCMA. The data has, however, shown that the case load has stabilised since 2002/03 and even declined slightly between 2004/05 and 2005/06. In addition, the data also suggests that the type of disputes referred to the CCMA as well as the shares of referrals by economic sector and region have remained relatively stable since the CCMA's inception. These observed patterns should make future planning easier for the CCMA, but does not retract from the fact that in terms of human resources and funding the CCMA is not equipped to deal with the current (or future) caseload.

Statistics from the CCMA's own database suggest that between 2001 and 2005, more than 30 percent of referrals were classified as "out of jurisdiction", meaning that the subject of the dispute falls outside the jurisdiction of the CCMA or that the referral is incomplete. ${ }^{13}$ In terms of jurisdiction, the dispute generally should have been referred to the Department of Labour or to an applicable bargaining council (Benjamin \& Gruen, 2006: 13). This represents a significant cost to the CCMA as these cases have to be screened before they can be rejected. In addition it places an administrative burden on the CCMA. On the positive side it does mean that inappropriate cases do not end up in conciliation or arbitration and cause congestion in the system (Benjamin \& Gruen, 2006: 16).

There is also the suggestion that the primary users of the CCMA are not necessarily those that were initially targeted. Levy and Venter (2006: 32) have shown that about 40 percent of referrals to the CCMA in 2004/05 were from while collar workers in professional services, banking, parastatals, tourism and financial services. "Unorganised" workers accounted for about 58 percent of referrals. It has been suggested that other bodies should take on dispute resolution functions so that those who were intended to use the CCMA (lower-level and unorganised workers) can be offered a better service (Roskam, 2007: 39). In line with this, the establishment of bargaining councils in well-organised sectors should be encouraged to relieve the burden on the CCMA where it comes to dispute resolution. While the LRA makes provision for the accreditation of private dispute resolution services, this has not happened. CCMA should proceed, as a matter of urgency, with the accreditation of private agencies in order to lighten its case load. Unorganised middle and higher skilled

13 There are no statistics available which indicate where these cases eventually end up - they can be submitted to the correct institution or re-referred to the CCMA if the technical issue has been resolved (also see Levy \& Venter, 2006: 22). 
workers should be encouraged to rather utilise these agencies (Roskam, 2007: 39). Labour law consultants can also play a role in encouraging skilled workers to rather approach these private agencies with their disputes.

In bargaining councils, the dispute resolution function is generally performed by staff of the council of council staff together with outside commissioners. Bargaining councils have, however, complained that the subsidy provided by the CCMA is insufficient and as a result the performance of the dispute resolution function has become a drain on councils' finance (Godfrey et al, 2007).

It has been suggested, that in order to reduce the number of referrals, a filing fee or the presentation of security for costs should be introduced for certain cases. The idea is that this may restrict access to the CCMA in such a way that inappropriate cases will be filtered out (Van Niekerk, 2007: 47). This may however also impact on the number of legitimate cases referred to the CCMA, particularly by vulnerable workers who cannot afford such a fee.

\section{Settlement Rates}

The CCMA has its own comprehensive list of internal and statutory measures of efficiency. Outcomes are compared against targets on a monthly basis to measure the efficiency of each of the regional offices of the CCMA. The efficiency measures are not necessarily comparable over time as dispute resolution measures adapt and evolve and as a result the efficiency measures are adapted too. Efficiency targets are also revised regularly (Bhorat et al, 2007: 22). A review of all these measures since the inception of the CCMA is, as a result, very difficult and also falls outside the ambit of the paper. We therefore only highlight the most important efficiency parameters and their outcomes. One of these is the settlement rate, which the requirement that at least 70 percent of the cases referred to the CCMA have to be resolved during the conciliation or arbitration process or withdrawn by the plaintiff (in other words "settled"). During the $2003 / 04$ to 2005/06 period this target was not met, with the settlement rate ranging from 56 to 62 percent (Bhorat et al, 2007: 22).

On the other hand it has been suggested that the CCMA commissioners may tend to settle cases too quickly in order to meet the settlement rate and other settlement 
targets. As a result cases are settled without the underlying issues being addressed and resolved properly. This may point to a need to review the settlement rate as an efficiency target.

\section{Speed of the processes}

The CCMA has been criticised for not resolving disputes as quickly as intended. The LRA sets targets for the time period in which a dispute should be settled, with specific target days for the difference phases of the dispute resolution process. These statutory targets are also used by the CCMA itself to evaluate its internal efficiently.

The turnaround time between referral and activation refers to the time between when a case is referred to the CCMA and the requirement information is captured. In the majority of cases the activation date is the same as the referral date, meaning that the turnaround time is zero. Delays result when information is missing in the referral and the applicant has to supply this information. Long delays do not necessarily reflect poorly on the efficiently of the CCMA as the client has to provide the information (Bhorat et al, 2007: 27). It does, however, add to the administrative burden of the CCMA.

In terms of conciliation, the LRA requires that no conciliation be conducted outside of the 30 day statutory period (that is, the requirement that conciliation has to take place within 30 days of referral of the case to the CCMA), unless both parties have agreed. The related efficiency measure is simply a count of the number of cases conducted outside the 30 days. Bhorat et al, (2007: 22) have shown that the target of zero cases was not achieved in the period 2003/04 to 2005/06.

The efficiency target in terms of turnaround time for conciliations is that cases must be finalised within 30 days of activation of the case. ${ }^{14}$ Both in 2004/05 and 2005/06 this target was missed with turnaround times actually increasing over the period from 33 to 45 days (Bhorat et al, 2007: 23). Using the CCMA's CMS data, Bhorat et al. (2007: 34 ) calculated that the average conciliation (including con-arb cases concluded at the

$14 \quad$ This efficiency target is different from the previous target but both follow from the statutory requirement that conciliation has to be conducted within 30 days of referral of the case. The fist target involves counting the number of cases conducted outside of the 30 days period, while the second target refers to the actual time it took to conclude the case during conciliation. 
conciliation phase) turnaround time was 36 days for the period 2001/02 to 2005/06.

The efficiency target for arbitrations requires that these cases must be finalised within 60 days of the referral to arbitration. ${ }^{15}$ Again this target has continuously been missed, with the estimated average turnaround times for arbitrations between 2002/03 and 2005/06 more than 100 days. The evidence does suggest that the situation has improved dramatically over the period, with the turnaround time reduced to about 80 days (Bhorat et al, 2007: 38). This, however, still implies that the average arbitration case takes about a third of the time longer than the target.

Another contributing factor to the delay in the turnover of cases is the number of in limine applications. An in limine application refers to the legal process where one of the parties to the dispute applies to have the case dismissed on a technical point that does not relate to the merits (facts) of the case (Benjamin \& Gruen, 2006: 31). After a sharp increase between 2001/02 and 2002/03, the share of in limine cases in the total caseload stabilised at around eight percent (Bhorat et al, 2007: 20). This, however, still amounts to a substantial number of cases every year. It also contributes to further delays as the continuation of the dispute resolute process depends on the outcome of the in limine application.

The lack of human resources at the CCMA has been highlighted as particularly problematic. Work overload reduces the effectiveness of commissioners as they are required to conciliate and arbitrate three to six cases a day. Due to the large number of conciliations scheduled for each commissioner every day, commissioners do not have enough time to conciliate cases properly and therefore do not have the time to address the causes and underlying issues of a dispute (Levy \& Venter, 2006: 53). Although the conciliation process is mandatory, legally there is no pressure to resolve a case at this stage and generally neither employees nor employers are eager to settle as this phase. When either of the parties does not attend conciliation hearings, the matter is automatically referred to arbitration. It has been suggested that employees have the impression that the longer the process is drawn out, the bigger the financial award will be. In addition, parties to the dispute also regularly apply for postponements before

15 This means the date from which the case was referred to arbitration - and not the date of the initial activation of the case. 
or at hearings (Levy \& Venter, 2006: 29). Some experts have suggested that CCMA commissioners should be more forceful in promoting conciliation as the preferred stage to settle a case.

The CCMA limits the number of cases any commissioner may postpone. The target in 2003/04 was one percent, but was increased to three and five percent respectively in 2004/05 and 2005/06. These targets were never reached, with postponements reaching about eight percent for each of the three years. The tendency for part-time commissioners to postpone cases has been raised as a cause for concern with some suggesting that because part-time commissioners work on a contract/hourly basis, they postpone for financial reasons (Bhorat et al, 2007: 23).

\section{Over-emphasis on procedural fairness}

In Section 3.1 on unfair dismissals, the issues around procedural fairness were highlighted - specifically the fact that employers and labour law consultants continue to interpret the LRA's requirements in a much stricter manner than was intended. There is a general perception that where it comes to procedural fairness, the CCMA also continues to "apply and demand procedural rights beyond those required by the Code of Good Practice" (Van Niekerk, 2007: 23; See also Levy \& Venter, 2006: 38). Legal experts in this arena have noted that CCMA commissioners may benefit from guidance and training in this regard.

\section{Impact of Labour Court decisions on the CCMA}

The Labour Court has a supervisory authority over the CCMA. The decisions made by the Labour Court are binding on the CCMA and the CCMA must fulfil its functions according to the way the Labour Court interprets the provisions of the LRA. In addition, all other stakeholders, including employers, trade unions and labour lawyers and consultants have to keep up to date with Labour Court decisions as they are handed down, as these provide guidance on how to interpret requirements of the LRA (Benjamin, 2006: 2).

Benjamin (2006) reviewed the impact of the Labour Court case law on the arbitration processes conducted at the CCMA, specifically highlighting how the different views of labour court judges have contributed to uncertainty and inconsistency in choosing 
the basic format or procedure for arbitration hearings. ${ }^{16}$ As discussed earlier, the LRA leaves it up to the CCMA commissioner to decide on the format of the arbitration process, based on the Labour Court's interpretation of the LRA's requirements. The key requirement is that he/she should deal with the "substantial merits" of the disputes with the "minimum of legal formalities". In addition, commissioners are also obliged to deal with the dispute "as quickly as possible". In practice, these two obligations can be at odds with each other.

In order to promote the speedy resolution of disputes, commissioners are allowed to "narrow the issues" (that is, limit the number of issues) to be dealt with during arbitration. The commissioner, however, has very little information prior to the start of the arbitration process to base this decision on and in practice the commissioner may end up ignoring some of the key issues. The Labour Court provides no guidelines on how to deal with the problem.

The Labour Court distinguishes between two main approaches an arbitrator can choose when conducting an arbitration hearing. An arbitrator can conduct hearings in an "adversarial" mode where the responsibility of questioning the witnesses is left in the hands of the parties and/or their representatives. Or an arbitrator can follow a more "inquisitorial" approach where he/she plays a more active role in uncovering the facts of the case. The Court does not allow a commissioner to change the format during the proceedings even if it will speed up the process and uncover more facts. This is very problematic if a commissioner has chosen an "adversarial" format and it becomes clear during the proceedings that one of the parties is not successful in presenting all the relevant facts. The commissioner is then not allowed to intervene to ensure that the substantial merits of the case are dealt with. A situation like this can occur because there are no guidelines which set out the factors a commissioner should consider when choosing the format for the hearing.

Overall, the issues highlighted above suggest that the Labour Court has not been very successful in fulfilling its supervisory function and this has impacted not only on the efficiency of the CCMA, but on the dispute resolution process as a whole. In addition, the lack of clear guidance from Labour Court judgements makes it very difficult to

$16 \quad$ Unless otherwise indicated, this sub-section draws on the discussion in Benjamin (2006). 
for the CCMA to draw up guidelines that will assist commissioners in choosing the correct format for hearings and also assisting them to make sure that they deal with the substantial merits of a case.

\subsection{Labour Courts}

The Labour Courts (consisting of the Labour Court and the Labour Appeals Court) were the second set of new institutions created by the 1995 LRA specifically for the resolution and settlements for labour disputes. The Labour Court can hear contractual disputes or disputes under the Basic Conditions for Employment Act or the Employment Equity Act, without the dispute first being subject to conciliation. The Labour Court is also responsible for the review of arbitration awards issued by the CCMA (Benjamin, 2006: 7).

The Labour Court was officially established with the enactment of the LRA in 1996. Initially three full-time judges were appointed to the court, supplemented by acting judges. No new full-time judges have been appointed since 2002, and since 2006 only two full-time judges have been serving on the bench of the Labour Court. As a result, the court is very dependent on acting judges and this reliance has been subject to substantial criticism (Benjamin, 2006: 7). In fact, one of the most severe problems currently facing the Labour Court is this reliance on acting judges.

The Labour Appeals Court (LAC) was established as the court of final instance in matters concerning the interpretation of the LRA and other matters within the jurisdiction of the Labour Court. The LAC was initially staffed by a full-time Judge President and a Deputy Judge President, but by 2006 the LAC only had a full-time Judge President, assisted by High Court judges and retired judges who generally only serve a term at a time (Benjamin, 2006: 7, 8). It was initially envisaged that the only matters with regard to which the LAC would not be the final court of appeal, would be constitutional issues, with the Constitutional Court as the final court of appeal. The Constitution, however, established the Supreme Court of Appeal (SCA) as the final court of appeals in all matters, except constitutional matters. The SCA has subsequently ruled that it is also the final court for appeals against the decisions of the LAC (Bhorat \& Cheadle, 2007: 16). This means that the SCA can overturn judgements from the LAC. 
In 2003, the draft Superior Courts Bill proposed that the jurisdiction of the Labour Court should be transferred to the High Court where its functions will be performed by judges taken from a list of judges with expertise in labour law. The Bill did not propose the establishment of a specialised Labour Court, but rather that cases should be heard by judges selected on the basis of their labour law expertise. It was also proposed that the functions of the Labour Appeals Court be transferred to the Superior Court of Appeals. Both business and labour representatives have registered their objection to these proposals and the feeling is that the integration of the Labour Courts into the High Court system will severely undermine the rights of both workers and employers. In addition the knowledge and experience associated with specialists Labour Courts will be lost if labour cases are heard in a general court. This issue, however, remains unresolved and the uncertainty has stalled the appointment of additional full-time judges to the Labour Courts (Benjamin, 2006: 9).

\section{Reviews of Arbitrations}

The LRA does not allow appeals against the outcomes of arbitrations. The rationale behind this was to avoid the high costs and time delays that are usually associated with appeals. The LRA instead makes provision for the Labour Court to review arbitration awards. In the case of arbitration awards, a review must be brought within six weeks of when the award was made, again highlighting the emphasis on speediness in arbitration cases. Labour Court judges are allowed to perform an appeal function and correct mistakes by CCMA arbitrators when required (Benjamin, 2006: 43).

The CCMA has estimated that about 20 percent of arbitration awards are subject to reviews. It has, however, also estimated that only about 20 percent of reviews that are instituted are actually processed to the stage of a hearing. This is being interpreted to suggest that reviews are used by employers to delay the enforcement of awards (that is, the payment of awards) to employees (Benjamin, 2006: 44). In reality, the review process causes major delays in the dispute resolution process. It is estimated that it takes on average 23 months to conclude a review and that only about a quarter of reviews which proceed to the Labour Court are successful. It is clear that the lengthy review processes run counter to the objective that labour disputes should be resolved quickly. 
Review proceedings mostly take place without input from the relevant commissioner or the CCMA. As a result, the decisions of the Labour Court do no engage with the practices and policies of the CCMA. In turn this impacts on the effectiveness of the supervisory role of the Labour Court on the activities of the CCMA (Benjamin, 2006: 45). The urgent need is to update the Code of Good Practice: Dismissal to present better and clearer guidelines to CCMA commissioners, particularly with regard to unfair dismissal cases, has again been highlighted. Updated guidelines will then (hopefully) reduce the number of reviews before the Labour Court. Generally, it has also been suggested that closer links should be forged between the CCMA and the Labour Courts in order to make the whole dispute resolution process more efficient.

The usefulness of the review process has been questioned and it has been suggested that it may be more appropriate to allow appeals against the decision of the CCMA in dismissal cases. The result will hopefully be a clearer body of Labour Court judgements which can be used as guidelines by the CCMA.

Currently there are no statistics available on reviews by the Labour Courts and it has been suggested that a case management database similar to the one used by the CCMA be developed to make it easier to evaluate the efficiency of the Labour Courts. Finally, it has also been suggested that the Rules Board of the Labour Court should be convened to update the rules of the Court.

\subsection{Summary}

The evidence presented above disputes any claims that bargaining councils contribute to inefficiencies in the South African labour market. Rather, the balance of the evidence seems to suggest that the key issue is how to address the current fragmented state of collective bargaining and the fact that the envisaged expansion of sector level bargaining did not occur. The promotion of sectoral collective bargaining and the formation of bargaining councils may have several possible positive outcomes. It has been suggested that it is the only viable way to extend protection to atypical (and particularly vulnerable) employees such as informal sector workers, casual workers and the self-employed. Increasing financial support for the dispute resolution functions of bargaining councils will also relieve some of the pressures on the CCMA. 
The CCMA is faced by a much higher number or referrals than initially anticipated and the accreditation of private agencies should be encouraged, along with the support for bargaining councils' dispute resolution functions. Delays in the settlement of cases have also been highlighted as a major challenge. It was however suggested that the emphasis on the speedy resolution of cases means that CCMA commissioners do not have the time or inclination to deal with the underlying issues of a dispute.

Both the CCMA and the Labour Courts have been criticised for their overly strict interpretation of the requirement for procedural fairness. The lack of proper supervision and clear guidance from the Labour Courts has also placed huge burdens on CCMA commissioners to determine the correct process to follow in resolving disputes. While the delays in the review processes in the Labour Court have been identified as a problem, the most critical problem is the lack of clarity about the future of the Labour Courts. This renders it impossible, in the foreseeable future, to address the staffing problems as well as efficiency problems. 


\section{Conclusion}

One of the key issues that appear common to all the debates concerning unfair dismissals, unfair labour practices as well as the efficiency of the labour market institutions, is the urgent need to update the Code of Good Practice to reflect recent decisions and judgments of the CCMA and the Labour Courts. In addition, some of the guidelines in the Code can be simplified, particularly with regard to retrenchments. This would be an important first step in the policy process around labour market regulation.

Another critical issue is the overly strict interpretation of the requirement for procedural fairness when dismissing employees for misconduct or incapacity. While employers, legal advisors as well as the labour market institutions all follow overly complex procedures, it has been suggested that the CCMA (supported by the Labour Courts) should lead by example and not demand more complex pre-dismissal procedures than those required by the LRA.

It has also been suggested that managers and skilled workers should be excluded from dismissal laws as they enjoy adequate protection under contractual law. Experts disagree on how SMMEs should be treated, with some suggesting that they should be excluded from all legal requirements in terms of dismissal, while others feel that a separate Code of Good Practice should be drawn up for SMMEs. When it comes to retrenchments, it has been suggested that requirements with regard to notification can be limited when less than a particular number of workers is retrenched.

There is general agreement that the LRA's definition of what constitutes an unfair labour practice with regard to promotion, demotion, training, benefits, discipline short of dismissal, suspension and failure to reinstate or re-employ, should be reviewed. While some experts suggest that all the unfair labour practices should be removed from the LRA, others prefer adding guidelines to the LRA or drawing up a separate Code of Good Practice to deal with unfair labour practices. Suspension pending disciplinary action is, however, very problematic, and requires immediate regulatory reform, particularly given the widespread abuse of suspension in the public sector.

It has been shown that there is no evidence to support the claims that bargaining councils contribute to inefficiencies in the labour market. The extension and exemption 
arrangements appear to work well and bargaining council membership is generally not associated with higher wages. The LRA's vision for a strong system of collective bargaining at sectoral level did not, however, materialise. Bargaining council coverage is highly fragmented and limited to only a few sectors. It has been suggested that the Department of Labour should become more pro-active in supporting sectoral collective bargaining. Collective bargaining at the sector level may be the best way to extend protection to atypical workers. Additional financial support for bargaining councils to fulfil their dispute resolution functions will also relieve some of the pressure on the CCMA, which is battling to deal with the high number of referrals.

In addition to the high number of referrals, the CCMA has also found it difficult to settle cases in the prescribed time frames. This is true for cases settled both at conciliation and arbitration. With CCMA commissioners under pressure to settle cases as quickly as possible, this means that they generally do not have the time to engage with the underlying causes of a dispute. This has highlighted the importance of accrediting private agencies as well as supporting dispute resolution at bargaining councils to relieve the pressure on the CCMA commissioners. In addition, skilled workers and bargaining council members should be encouraged to refer disputes to private agencies or the relevant council.

The Labour Courts have not succeeded in providing proper supervision and clear guidance to the CCMA commissioners in terms of the correct processes to follow when resolving disputes. Widely different judgements from the Labour Court have contributed to inconsistency and uncertainty where it comes to choosing the correct approach. There is general agreement that closer links should be forged between the CCMA and the Labour Courts to improve the efficiency of the dispute resolution system as a whole. The Labour Courts should provide clear and consistent guidelines for the CCMA and should engage with the CCMA when reviewing awards.

The most critical issue remains, however, the lack of clarity around the future of the Labour Courts. This makes it impossible to address the current shortage of full-time Labour Court judges and it also means that any further research to evaluate the efficiency of the Labour Court in terms of the review process may prove to be futile.

Ultimately though, the paper has provided a contemporaneous overview of some of 
the key legal debates around labour market reform in South Africa since the 2002 amendments. It is principally in trying to decode these debates for non-legal readers, however, that the paper hopes to broaden the debate and discussion around labour market regulation in South Africa. 


\section{Bibliography}

Bhorat, H. \& Cheadle, H. 2007. Labour Reform in South Africa: Measuring Regulation and a Synthesis of Policy Suggestions.

Bhorat, H., Pauw, K \& Ncube, L. 2007. Understanding the Efficiency and Effectiveness of the Dispute Resolution System in South Africa: An Analysis of CCMA Data. Development Policy Research Unit. Draft Paper. September 2007.

Bhorat, H., van der Westhuizen, C., \& Goga, S. 2007. Analysing Wage Formation in the South African Labour Market: The Role of Bargaining Councils. Development Policy Research Unit. Draft Paper. September 2007

Benjamin, P. 2006. Friend or Foe? The Impact of Judicial Decisions on the Operation of the CCMA. Development Policy Research Unit. December 2006.

Benjamin. P. \& Gruen, C. 2006. The Regulatory Efficiency of the CCMA: A Statistical Analysis of the CCMA's CMS Database. Development Policy Research Unit Working Paper. No 06/110. June 2006

Benjamin, P. \& Theron, J. 2007. Costing, Comparing and Competing. Developing an approach to the benchmarking of labour market regulation

Besley, T \& Burgess, R. 2004. Can Labor Regulation Hinder Economic Performance? Evidence from India. In Quarterly Journal of Economics. Vol 119. Issue 1. February 2004.

Cheadle, H. 2006. Regulated Flexibility and Small Business: Revisiting the LRA and the BCEA. Development Policy Research Unit Working Paper. No 06/109. June 2006

Godfrey, S., Maree, J. \& Theron, J. 2006. Conditions of Employment and Small Business:

Coverage, Compliance and Exemptions. Development Policy Research Unit Working Paper No 06/106, March 2006. Cape Town: University of Cape Town.

Levy, A. \& Venter, T. 2006. Conciliation and Arbitration and the settlement of disputes of right in South Africa. In Tokiso Review 2005/06. The First Annual Report on the State of Labour Dispute Resolution in South Africa. Johannesburg: Tokiso Dispute Resolution Settlement (Pty) Ltd

National Treasury (formerly Department of Finance). 1996. Growth, Employment and Redistribution: A Macroeconomic Strategy. Pretoria: Government Printers. 
Republic of South Africa. 1995. Labour Relations Act. No 66 of 1995. Available from http://www.info.gov.za/documents/index.htm

Republic of South Africa. 1996. Constitution of the Republic of South Africa. No 108 of 1996. Available from http://www.info.gov.za/documents/index.htm

Republic of South Africa. 1997. Basic Conditions of Employment Act. No 75 of 1997

Republic of South Africa. 2008. Basic Conditions of EmploymentAct, 1997. Determination: Earnings Threshold. Government Gazette. Vol. 512, No 30720. 1 February 2008. Government Printer: Pretoria

Roskam. A. 2007. An Exploratory Look into Labour Market Regulation. Development Policy Research Unit Working Paper. No 07/116. January 2007

Van Niekerk. A. 2007. Regulating Flexibility and Small Business: Revisiting the LRA and BCEA A Response to Halton Cheadle's Concept Paper. Development Policy Research Unit Working Paper. No 07/119. March 2007 